\title{
Lineamientos para el desarrollo de herramientas educativas interactivas para la estimulación temprana a nivel psicomotriz en niños de 3 a 5 años de edad validados a través de un prototipo experimental
}

SOFTWARE ENGINEERING

\section{Guidelines for the development of educational interactive tools for early psychomotor stimulation in children ages 3 to 5 years old, through an experimental prototype}

\author{
Alexandra Ruiz *§, Alexa D. Cortés *, Jorge I. Gómez * \\ * Programa de Ingeniería de Sistemas y Computación Universidad del Quindio, Armenia, Colombia \\ §aruiz@uniquindio.edu.co,alecm20@hotmail.com,joimole1008@hotmail.com
}

(Recibido 6 de Abril de 2013 - Aceptado 12 de Octubre de 2013)

\begin{abstract}
Resumen.
La industria del software está centrando sus esfuerzos en el sector de edades que comprenden la etapa de educación infantil aprovechando las cualidades multimedia de la tecnología existente. Sin embargo, estas cualidades tecnológicas no son suficientes. Para que un software sea de calidad y cumpla con el objetivo de educar debe ajustarse a características específicas de los usuarios finales. De esta manera, con el fin de hallar estas características específicas se realizó una exploración de diferentes herramientas educativas para niños de la primera infancia a través de un estudio cuasi-experimental. A partir de los resultados se generaron lineamientos a tener en cuenta en el desarrollo de herramientas educativas interactivas para el desarrollo psicomotriz en niños de 3 a 5 años de edad, los cuales fueron validados a través de un prototipo experimental llamado "Jugueteando en mis primeros pasos." Los productos de la investigación pretenden aportar buenas prácticas para los desarrolladores de software que tienen como objetivo este tipo de usuarios, además de presentar una herramienta potencial de apoyo pedagógico en los procesos de estimulación para el desarrollo psicomotriz.
\end{abstract}

Palabras clave: desarrollo de software, estimulación psicomotriz, herramientas interactivas, software educativo.

\begin{abstract}
.
The Software Industry is focusing its efforts on age groups which involve childhood education, leveraging the multimedia capabilities of current technology. However, these technological qualities are not enough. In order to create quality software with education objectives, it has to adjust to specific characteristics of the final user. Hence, with the purpose of finding these specific characteristics, different educative tools for children in early childhood were explored through a quasi-experimental study. Based on these results some guidelines were generated for the development process of educative interactive tools for psychomotor development of children between 3 and 5 years old, which where validated through an experimental prototype called "Playing whilst taking my first steps". The products of this research are intended to provide best practices for software developers who target those types of users, and to present a potential tool for pedagogic support in stimulation process for psychomotor development.
\end{abstract}

Keywords: educational software, interactive tools, psychomotor stimulation, software development. 


\section{Introduction}

Educative technology and the theoretical emphasis associated with teaching/learning activities during the twentieth century impacted educational practices in these educational organizations. The training of teachers, selection, use and evaluation of media allowed the assessment of contributions to educative system without neglecting the concepts of learning theory and didactic contribution to improvements in the twentieth century (Ferrer $\&$ Salas, 2009).

Subsequently, in recent years the software industry is focusing its efforts on the age range of Childhood Education, under the old formula "playful learning", and taking the utmost advantage of multimedia qualities offered by computer equipment (Urbina, 2000). Therefore nowadays, educative tools can be acquired whose users include even those less than three years old. However, for a didactic material to be efficient in child learning, it is not enough to have "good material", nor is it necessary to have the latest technology. When selecting educative resources to use in teaching, besides its objective quality, metrics of specific characteristics should be considered. (Ministerio de Educación y Cultura Española, 2003).

For that reason, when building educative tools, besides considering general guidelines for its development, guidelines and specific characteristics should be taken into account. Following this statement, this research is focused on generating specific guidelines for the development of interactive educative tools for psychomotor development of early childhood in children between 3 and 5 years old, which where validated through an experimental prototype called "Playing while taking my first steps". The psychomotor area has been selected as it is of vital importance to the achievement of childrens' independence, that is, the control of his/her own body (Bermejo, 2010). Similarly, psychomotor skills enable the integrated development of a person, as it approaches indivuals as a whole, taking affective, social, intellectual and motor aspects into account. It is a discipline on which all learning is based, and its objective is to help express emotions through the body, encouraging development (PsicomotricidadInfantil, n.d).

The experimental prototype, besides taking into account specific guidelines generated during the research phase, is based on a series of Preschool Curriculum Guidelines (MEN, n.d), turning it into potential didactic material for children pedagogical staff.

It is noteworthy that this project was born from a necessity to see a society with better educative expectations and that an impulse is necessary if a cultural transformation is desired where new and better educative projects are developed in a short term, but which impact an entire lifetime.

In this way, this article starts off with a description of how the research on existing software was carried out. Subsequently, specific guidelines generated from performed tests, and the construction of an experimental prototype are described. Finally, obtained results are presented, as well as conclusions and future work.

\section{Methodology}

An assessment of existing educative software targeting children between 3 and 5 years old was chosen as the first research objective; with the intention to futher identify its advantages and disadvantages through a usability test. From these test results specific guidelines were generated for the psychomotor development of children between 3 and 5 years old. The following sections specify the activities of the process.

\subsection{Research on educative software}

The selection of materials to use with students should always be done under contextual control in the design frame of a concrete educative intervention, considering all corresponding curriculum aspects (UPD IMELSA, n.d). Considering this, a variety of educative software was consulted to select the didactic material, where there was an obvious lack of important aspects such as: congnitive procedures, animation 
and multimedia guides, which restricted the selection possibilities of educative software more in line with contents and cognitive developments in children between 3 and 5 years old.

In the following sections the selection process is detailed.

\subsubsection{Identification of representative software in the level of psychomotor development}

For the selection of educative tools to be used in teaching labor, its specific characteristics should be considered (Ministerio de Educación y Cultura Española, 2003):

The educative objectives that are to be achieved: it should be considered how much the material could help achieve the objectives.

The contents to be treated using the material: they should be in tune with the contents of the course followed by the students.

The characteristics of the students using the materials: this refers to the capabilities, cognitive styles, interests, previous knowlegde, experience, and skills required for the use of these materials. Every didactic material requires certain prerequisites from its users.

The characteristics of the context (physical, curricular) in which teaching is developed and the training of the students where the didactic material to be selected is to be used: depending on the context it could be recommended not to use the material, even if it is of good quality.

The didactic strategies to be designed considering the use of the material: these strategies consider the sequence of contents, the set of proposed activities for students, the methodology associated to each activity, the educative resourses to be used, etc.

With these characteristics in mind, a search was performed of tools oriented to the psychomotor development of students between 3 and 5 years old, with contents according to each age goal and with possible use of these tools in classrooms with basic computer resources.

\subsubsection{Selection of educative software for psychomotor development of children between 3 and 5 years old}

After identifying the list of educational tools to be adjusted to the stipulated specific characteristics, a pre-selection of educational software was performed taking into account the most relevant characteristics obtained by a preliminary study done with a population sample intended for evaluation. The results obtained in the pre-selection of this first evaluation stage show 5 educative tools as the most promising, which were subsequently selected to carry out the evaluation plan with the total population. The pre-selection of educational software was done based on the approval users had with them, i.e. those that aroused great curiosity during interaction and also directly stimulated the psychomotor conduct of users. Finally, the selected educated tools were: El Conejo Lector Preescolar, Pequetic, Aprende a Leer con Pipo, Winnie The Pooh Kinder, Dikie and Dukie.

The most relevant characteristics that allow for the selection of educative software emphasize depth during the interest stage, which in this case is the stage of childhood: children between 3 and 5 years old. These characteristics were represented in the following cognitive processes:

Psychomotor area: technique which tends to favor corporal movement control, the relation, and the communication that children will establish with his/her surrounding world. This globality of children shown by their actions and movements that emotionally tie them to the world must be understood as the narrow link, which exists between their somatic and their affective-congnitive structure. In its linguistic analysis the term Psychomotor has two components; Motor and Psychism. These two elements will be the two faces of a single process: integral development of a person (Martín, 2002). The term motor refers to movement. The term psycho designates the physicic activity it its two components: socioaffective and cognitive.

Starting from the previous concept, phycomotor activities are set forth which are present in the 
selected pedagogic tools: a) stroke activities like complete draws and shapes, b) activities which use basic spatiotemporals like up-down, forwardback, before-after, fast-slow. For instance: an activity to put a geometric figure in a container. c) Activities to differentiate segments and corporal elements, for instance: dragging elements of human face. d) Displacements: run and stop; for instance locate constantly moving objects. e) Global activities through imitation, for example: imitating animal sounds when clicking on them.

Perceptive area: technique that allows for the development of visual/auditory/tactile perception, attention, and imitation (Hurlock, 1994). In the performed analysis of the selected educative software, it can be observed that there is a vast amount of media developed in this area. Some examples are sounds, images, textures and colors.

Socio-affective area: covers two parts, the social part and the affective or emotional part. Social development is defined as the acquisition of the capacity to behave in accordance with social expectations (Hurlock, 1994). This area is also defined as the socialization process in which children learn the fundamental rules for their adaptation to the social environment (Hernández, 1982). According to these definitions, activities where animal, people, and nature are involved are part of what the selected software provides to the social development.

The emotial study of children is difficult, because information gathering can only come from introspection, a technique that children cannot use successfully when they are still too little (Hurlock, 1994). Because of this, it is difficult to represent a playful interactive medium for a specific user, because of its variety and emotional diversity.

Logical-mathematical area: refers to the creation of basic, logical, mathematical, spatial and temporal relations; acting on different objects and reconciling opposing views. This aspect is reflected in the mathematical activities of the selected software, such as establishing geometric shapes groups according to their size and color.
Reading and writing area: the ability to read and write properly. It refers to a period where children, between 4 and 6 years old, learn to read and write. In reality, it does not refer to a defined concept but a compound process of many concepts.

Learning to read and write occurs in the same way as learning oral language. Like talking, writing is a form of language; therefore, the same has to be learned by means of authentic events that satisfy childrens' needs (Guerra \& Cuevas de Jesús, 1994).

Language is indivisible. To learn how to read, we cannot "break up" language into small pieces like isolated syllables or words. This fact makes learning literacy a difficult and unreal task. Besides, the art of language is not divisible; talking, listening, read and write must be taught in an integral way (Guerra \& Cuevas de Jesús, 1994).

According the above definition, reading and writing are of big importance while developing or stimulating psychomotor behavior, but the analysis of the tool shows a completely different reality, as few children develop this area according to their learning level in educative institutions.

\subsection{Research of educative software}

After considering the selected material, the next step was to gather data with the intencion of identify advantges and disadvantages of the 5 selected application, to do so, a quasiexperimental study was achieved in a single group (Rodríguez \&Valldeoriola, 2009).

\subsubsection{Subject of study}

The study was carried out in a group of 12 children, preschool students of first childhood, from Atenas preschool located in the city of Armenia, Quindío (Colombia).

Children were selected considering the next characteristcs: 3 , 4, or 5 years old, no previous contact with computers of educative software (irrelevant), no evident learning difficulties 
(irrelevant), approved first level preschool education (irrelevant), no apparent physical difficulties, good disposition of parents and school directors to create the experience.

\subsubsection{Work plan execution}

The work plan was structured in two phases. In the first phase, professors observed and interacted with the selected education tools, with the goal to have them give their consent to carry out the tests with the children. In the second phase, the selected tools were put into practice. In this second phase, the children attended 2 (two) work sessions in a class room of the Atenas school, during 2 days for approximately 5.5 to 6 hours per session. Attendance was indivually, each child with a computer, and in addition a mediator assisted each child.

As an instrument of evaluation, an observation guide was designed for the cognitive, psychomotor and infantile lenguage aspects of preschool children that attended the sessions. The instrument was applied according to three diferent aspects. For the first aspect, the results allowed for the detection or diagnosis of the current and real situation in which children started learning the proper area of language or the contents to provide them, as well as their attitudes about computers, thus specifying to some degree cognitive difficulty and conceptual management. The second aspect of the development intended to measure the progress level of children in aspects determined by the applied instrument, and in accordance with the objectives. To clarify, advances in a congnitive or psychomotor level were not the goal, but rather to observe what level a child can reach when interacting with the educative tools.

The third and last aspect was to compare the results between different phases, in order to come to some conclusions about the research objective.

The results of this evaluation were qualitatively measured and supervised by Professor Luisa Fernanda Beltrán Tovar, Pedagogue and Linguist from the University of Quindío, who provided essential observations on pedagogical and psychomotor level during children and software interaction.

\subsubsection{Advantages and disadvantages of the analyzed educative tools}

Next, a summary is presented about the most significant advantages and disadvantages of the evaluated tools.

Winnie the Pooh Kinder and Pequetic were applications with more cognitive orientation towards learning, meaning, the stimulation of psychomotor area. Additionally, these applications had the didactic characteristics and instructions required, for instance: written instructions, exercises and reinforcements and well organized lessons. On the other hand, Diki and Dukie, Conejo Lector Preescolar y Aprenda a Leer con Pipo have a high evaluation level but their pedagogic orientations were centered mainly in areas of cognitive development: sensitive, socio affective, logical-mathematical and reading and writing.

\subsubsection{Guidelines for building educative interactive tools for psychomotor development}

During the exercise performed in Atenas School and during the analysis of advantages and disadvantages of the evaluated tools, some guidelines or best practices were generated to consider when building educative interactive software to stimulate during first years the psychomotor behavior of children. These guidelines are presented in Table 1 and 2.

\subsection{Description of the experimental prototype "Playing while taking my first steps"}

Initially, for the development of the experimental prototype, capabilities developed by children between 3 and 5 years old were identified: motor, adaptive, language and personal-social behavior characteristics. Afterwards, those capabilities which can be exercised with the help of interactive tools, and which allow the application of generated guidelines to stimulate the balanced development of their abilities and skills. Between those preselected capabilities are listed:

3 years old children: walk forward, backwards, tip/toe, on the sides and heels; can recognize two parts of a figure and join them, can jump and bounce on either foot. 
Table 1. Guidelines at the interaction level to build educative software for psychomotor stimulation

\begin{tabular}{l} 
Interaction \\
\hline 3 year old users have low cognitive and language development in comparison with 4 and 5 year old users; for \\
that reason, it is needed to separate activities according to the complexity level per user. \\
When software provides stimulation using accomplishments, the software must not use diminutives. This \\
causes psychological limitations. \\
It is important to create associations of written words with auditive words; this helps children to relate the \\
grapheme with the phoneme. Require fine movements. \\
During painting and coloring activities, it is recommended to limit software to real color relations. It is \\
recommended to use a model to clarify how to paint objects so user has a reference. \\
In all activities, the mouse pointer must be big enough, so users can finish their activities appropriately. \\
Likewise, activities should not use click-drag to drag objects. \\
Some tools do not require users' complete accuracy, only approximations, which is ideal for users with fine \\
motor deficiencies. \\
Attractive auditive media is recommended to get attention of users. \\
Color palette, should have an appropiate size so users with different ages, can use their movement to perform \\
their activities. \\
Users require mentoring to understand games instructions. \\
Sometimes users orally count numbers having some mistakes, in some cases graphemes, numbers, letters \\
or symbols are not recognized. For that reason, it is important not to limit users with the software time to \\
develop some activities. \\
Users need some time to adapt and to perform activities without difficulties. \\
It is important giving scores to motivate users' performance.
\end{tabular}

Table 2. Guidelines at the activity level to build educative software for psychomotor stimulation.

\begin{tabular}{l} 
Activities \\
\hline Selecting shapes activities are very important for motor development and for mental development of users. \\
It is recommended to use only basic and not complex geometric shapes. \\
It is important to create associations of written words with auditive words; this helps children to relate the \\
grapheme with the phoneme. Require fine movements. \\
In memory activities it is important not to exceed the amount of elements in the activity, between 6 and 10 is \\
ideal. \\
It is recommended to combine languages during activities, but in addition to images and sound, a letter should \\
be included. \\
It is recomended to use games with levels to require fine movements from users. \\
Activities where animals and its sounds are involved, are ideal to develop cognitive abilities in users. \\
Users should be completely autonomous when performing the proposed activities.
\end{tabular}

4 years old children: they like wordplay, make larger sentences, and dance with more rhythm. 5 years old children: distinguish between left and right of themselves, can intelligibly count up to 10 objects, and differentiate between boys and girls games.

The list of abilities which could be exercised by interactive tool means is still extensive, but only some were selected according to each age because the intention was to make a prototype to test the guidelines instead of making a profitable tool.

\subsubsection{Design aspects}

"Playing while taking my first steps" is a hardwaresoftware system (see Fig.2) for teaching-learning environment with a workstation under conditions proper of the educative system, aiming the stimulation of user psychomotor skills.

The prototype was designed and implemented using the Usability Engineering Process Model and Accessibility (Granollers, Lorés \& Cañas, 2005), incorporating software engineering activities. The prototype has peripheral devices, 
keyboard and rug (see fig 2.b), creating a new environment in user learning process. The rug is the scenario where children develop different mental operations such: identification, comparison, virtual relation, direction and motor. Withing keyboard functions are: being a channel to add more reality whereas reducing abstraction to the user experience, an element to manipulate and to provide a different view in contrast with traditional interfaces of educative software.

The interface design and navigation is oriented to satisfy user: professors and first childhood children needs, with a friendly environment per activity.

\subsubsection{Prototype functionalities}

Functions provided by the prototype "Playing while taking my first steps" are oriented to psychomotor development or first childhood children of 3, 4 and 5 years old in areas such: language, motor, adaptatived behavior and personal-social behavior. In Table 3, implemented games are listed as well as abilities that those games reinforce according to children age.

Besides the proper functions of games, the tool include others for the management of involved users data (students and professors), games and psychomotor data querying and, evaluations and reporting

\subsubsection{Prototype test}

The Experimental prototype tests were focused on the evaluation of usability, as these better coupled the evaluation of generated guidelines.

The performed usability test used two approaches: cognitive pathways (Granollers, Lorés \& Cañas, 2005) and heuristic evaluation of Nielsen (Nielsen, 1993). These techniques selection were based on a study of (Lopez \& Salazar, 2010), in which these are categorized

a)
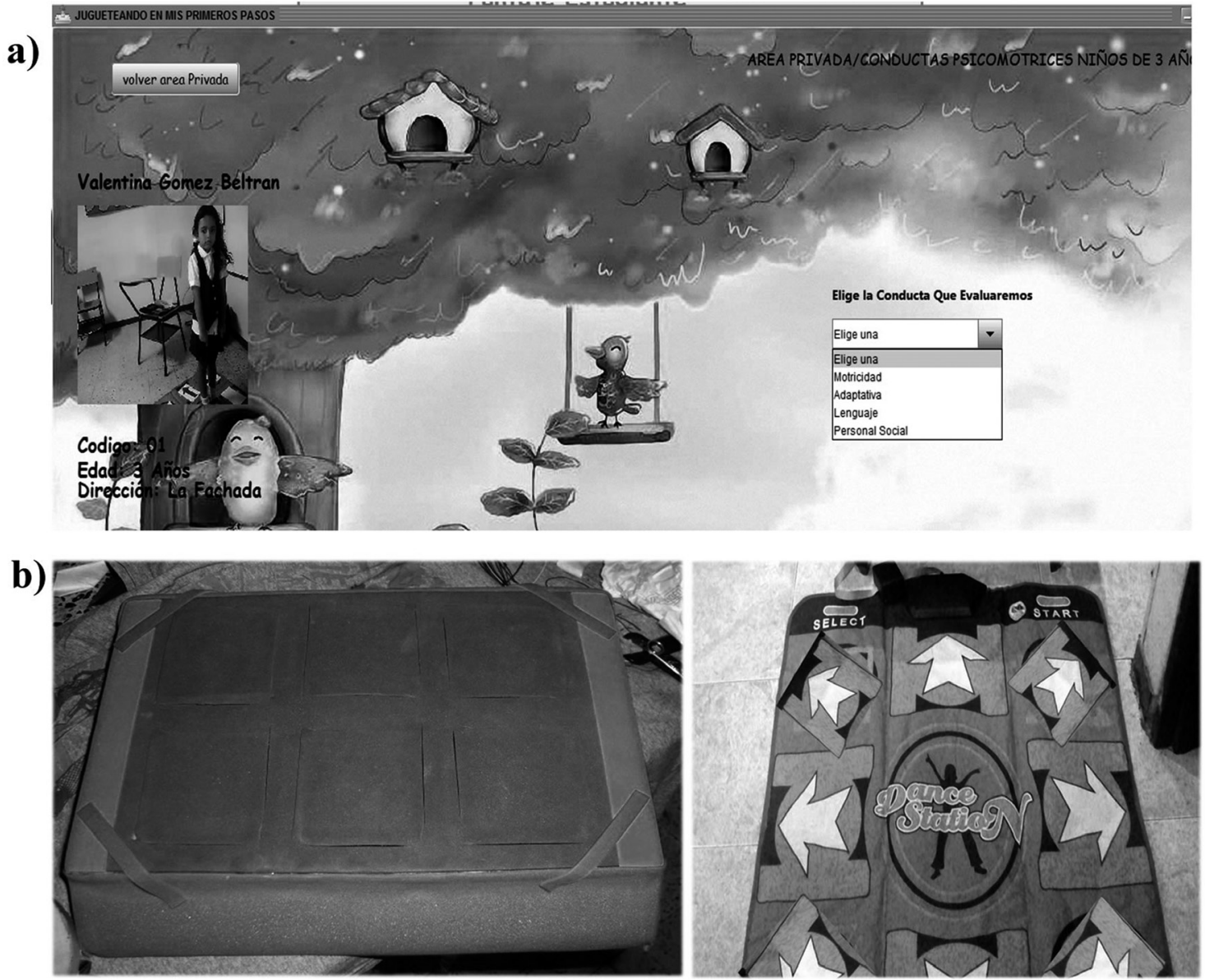

Figure 1. a) Evaluation interface for the student b) peripheral devices of the prototype (keyboard and rug) 
Table 3. Prototype games classification accorging to ages.

\begin{tabular}{|c|c|}
\hline \multicolumn{2}{|r|}{3 year old children } \\
\hline Game & Strengthen \\
\hline Animal recognition & Logical reasoning, visual abilities and spatial reasoning. \\
\hline Body recognition & Touch sense and attention. \\
\hline Vowels and directions in space recognition & Touch sense, visual, auditive abilities and attention. \\
\hline Food recognition & Auditive and visual capability, relation with reality. \\
\hline \multicolumn{2}{|r|}{4 year old children } \\
\hline Game & Strengthen \\
\hline The Way & $\begin{array}{l}\text { Spatio-temporal location, virtual projection and motor } \\
\text { development. }\end{array}$ \\
\hline Locating objects & Logical reasoning, comparison and identification \\
\hline Combining elements & Logical reasoning, comparison and identification \\
\hline Moral sense identification & Visual, auditive capability. Environment relation development. \\
\hline \multicolumn{2}{|r|}{5 year old children } \\
\hline Game & Strengthen \\
\hline Body movement through face profiles & Coordination, spatio-temporal orientation, visual capability. \\
\hline Puzzle & $\begin{array}{l}\text { Logical-mathematical thinking, identification, comparison and } \\
\text { virtual projection. }\end{array}$ \\
\hline Objects comparison & $\begin{array}{l}\text { Logic thinking, identification, comparison, auditive and visual } \\
\text { capability and mental agility. }\end{array}$ \\
\hline Cleaning your room & Identification and comparison. \\
\hline
\end{tabular}

as the most used and the most efficient. Cognitive pathway was done with two groups, 4 pedagogic professors and 15 children between 3 and 5 years old.

In the test of professors, specific tasks to be performed were identified. Task factors to evaluate were: time needed to accomplish the task, amount of errors, amount of questions inquiry to solve an error or a doubt and if the users ask for help.

Before starting, each user was explained about his/her tasks to perform and was given a small introduction about the purpose of the system. After completing their tasks, users answered a survey to complete the evaluation. This survey has three sections. The objective of the first section was to get information about the user expertise level with the built hardware (keyboard and rug) and the relation that software had with this hardware. Second section had questions with differential semantic emphasis ( strong $=3$, normal $=2$, weak $=1$, none $=0$ ) oriented to evaluate software interaction. The last section contains two open questions where users could give suggestions about interface changes and configuration settings of the system.
Fifteen children from Atenas School from Armenia city participated in testing. Their ages were between three and five years. The corresponding professors participated too. The test process had three phases. In first phase, authors observed each child using the prototype to verify its functionaly and the user-application interaction. Initially it was desired to see the reaction of children in front of the main menu and the application itself, the intent was to evaluate the placement of the screen elements, and their size and color, as well as how easy it is to recognize the elements. Then, it was verified if children were able to associate virtual and real objects and also how friendly and how easy the identification activity was, linking and selecting each figure in the corresponding place in the keyboard. Finally, it was checked if children were able to identify special signs given by the game to be represented through the rug. The second phase involved professors who assisted the children in the use of the prototype.

With the intention to evaluate what was described in testing phase, during the third phase, a form was designed for professors, which has the propositions regarding to the usability 
prototype based on the learning methodoly required to stimulate motor, congnitive and auditive abilities of preschool children. These propositions have to be qualified on a scale from zero (0) to ten (10), where zero means in complete disagreement and ten in complete agreement. For the heuristic evaluation, the 10 heuristics of Nielsen (Nielsen, 1993) were used, and 4 usability experts were asked to carefully analyze the interface, and point out the parts which functioning was against any principle.

\section{Results and discussion}

In work sessions carried out in software educative reseach, children show amazement, distrust, shyness and restlessness. There was no absolute dependence on the professor. These reactions were expected by researchers of the process, facing an unknown environment different from the one they are used to, and where scholar activities are developed. This explains their reaction. However, as shown later, all the concerns children showed were overcome and it can be said that their experiences were internalized as new ways of learning and social interaction.

In the level of the experimental prototype, the test results of cognitive pathway with professors give some software interface correlations as well as some suggestions about the tools' objectives: increasing the amount of games, periodic system updates, increase of animations and interpretation of the obtained average acquired by the evaluated student.

To obtain a quantitative conclusion of the survey answers, the mean of each answer was calculated given weights to the scale of questions with differential semantics.

Thus, it can be concluded that:

a) the system was nice to the group of evaluated professors $($ mean $=3$ )

b) the answer generated by the software during interaction, has strong relation with its pedagogic content $($ mean $=3)$

c) lack of auditive animation in the answers given by the software $($ mean $=2.4)$ d) the software content shows in a clear way the curricular guidelines which must be oriented to children between 3 and 5 years old $($ mean $=3$ )

f) interaction with software is very intuitive $($ mean $=2.8)$,

g) the group of professors consider that the system purpose is very interesting and useful to guide education at the pedagogic level $($ mean $=3)$

h) the group of evaluated professors consider that the system provides enough options to interact with the software in an effective way $($ mean $=2.6)$

i) how useful information about congnitive areas is to carry out the execution of the game and reinforce the professor knowledge $($ mean $=3)$

Regarding usability, in test results completed by children between 3 and 5 years old it was perceived that children show a real interest to use the prototype. Sounds and colors used on the interface motivated them to discover what was in each section. Element positioning on the screen enabled children to explore the application. Size and color of the figures made visualization easy and the used objects were easy to recognize by children. When presenting different activities, children were paying attention to the screen, following with their actions the guidance given by each mediator in every task. The association of objects between screen, keyboard, and color objects classification, where activities easier to achieve, as children feel familiarized with figures shown by the software as well as basis colors.

Concerning propositions evaluatedby professors, once each test finalized, it was noticeable that $100 \%$ of professors were in agreement with the proposition "Children keeps prolonged attention on applications while performing the activities". Propositions consider: exploration of the children capabilities, promptness of the activities' occurrence, association, selection, classification and objects naming, precision and coordination of children movements, visual and auditive differenciation, oral and clear instructions, keyboard use, rug as input device, 
type and size of images, visual and auditive feedback, getting grades between 8 and 10, which correspond to the Zone Of Complete Agreement Proposed.

Regarding heuristic tests results, expert reviewers agree that the prototype has a simple and natural dialog, talks the same user language, appropriate management of error messages, and has a clear and simple manual, easy to understand. It was suggested to reduce the number of clicks to perform some activities and increase the user selection and search criteria, with the intention to reduce the cognitive charge of users.

\section{Conclusions}

Through research, it was possible to generate specific guidelines for the development of interactive tools; tools used for the psychomotor development of children between 3 and 5 years old. The application of these guidelines generated a prototype. According to the test results, the prototype had good acceptance by users. There was a clear understanding about motor, communication, language and sociopersonal relation activities shown in the games of the tool. In the same way, professors understood their role in the mediation process to establish a link between children and software. They also understood that their role was mainly to provide children with the necessary support to stimulate their zone of close development.

As future work it is suggested to research on specific guidelines for the development of interactive tools to stimulate other first childhood areas, such as: logical-mathematical, reading and writing, social-affective, among others. Similarly, it is proposed to maximize functions and peripherals of the prototype, with the idea of building a pedagogic support tool for stimulation process related to the psychomotor development thereby, transforming traditional lectures into innovative ones.

\section{References}

Bermejo V. (2010). La importancia de la psicomotricidad en la etapa de infantil . Revista
Autodidacta. [online] 1(3). Disponible en: $<$ http:// anpebadajoz.es/autodidacta/ $>$ [Consultado: 8 de Febrero de 2012].

Ferrer, M., and Salas, F. (2009). Enfoques teóricos y definiciones de la tecnología educativa en el siglo XX. Revista Electrónica Actualidades Investigativas en Educación, [e-journal] 9(2). Disponible en: <http://redalyc. uaemex.mx/redalyc/pdf/447/44713058004. pdf $>$ [Consultado: 15 de Marzo de 2012].

Granollers, T., Lorés J., Cañas, J. (2005). Diseño de Sistemas interactivos centrados en el usuario. UOC.

Guerra, C. and Cuevas de Jesús, E. (1994). Lenguaje integral y lectoescritura. Revista Cuaderno de Investigación en la Educación. [online] Disponible en: <http://cie.uprrp.edu/ cuaderno/ediciones/08/c8art2.htm $>$ [Consultado: 13 de abril de 2012].

Consejo Operativo NacionalparalaEstimulación Temprana. (1982). Guía Curricular para la estimulación del desarrollo integral del niño menor de seis años. San José de Costa Rica, Costa Rica, Ministerio de Salud.

Hurlock, E. (1994). Desarrollo del Niño. México: Editorial McGraw Hill.

Lopez, D., and Salazar C. (2010). Adaptación de los métodos de inspección de evaluación de usabilidad para ambientes colaborativos $e$ implementación de una herramienta colaborativa para la evaluación heurística de proyectos software. Armenia, Universidad del Quindío.

Martín, L. (2002). La Estimulación Temprana: Sus Objetivos. Disponible en: <http://www. fnp.es/detalle_especialista.php?ID $=172 \mathrm{v}>$ [Consultado: 23 de Marzo de 2012].

Ministerio de Educación Nacional. n.d. Serie de Lineamientos curriculares: Preescolar. [online] Disponible en: $<$ http://www.mineducacion.gov. co/cvn/1665/articles-89869_archivo_pdf10. pdf $>$ [Consultado: 20 de Marzo de 2012]. 
Ministerio de Educación y Cultura Española. (2003). Libro Blanco de la Educación en Castilla- La Mancha: Diseño Curricular Base en Educación Primaria. [online] Disponible en: <http://www.uclm.es/profesorado/ricardo/ DCBPrimaria.zip> [Consultado: 15 de Marzo de 2012].

Nielsen, J. (1993). Usability engineering. Boston: Academic Press.

PsicomotricidadInfantil. n.d. Qué es la psicomotricidad?. [online] Disponible en: $<$ http://www.psicomotricidadinfantil.com/ psicomotricidad-infantil.html $>$ [Consultado: 1 de Febrero de 2012]
Rodríguez, D., and Valldeoriola, J. (2009). Metodología de la investigación. Barcelona: Editorial Eureca Media.

UPD IMELSA VI. n.d. Manual de Orientación Metodológica. [online] Disponible en: $<\mathrm{http} / / /$ www1.ocupacio.gva.es:8084/adient/mediateca/ general/educacion/manualmetodologia.pdf/ view $>$ [Consultado: 10 de Febrero de 2012].

Urbina, S. (2000). Algunas consideraciones en torno al software para Educación Infantil. Revista Electronica de Tecnología Educativa [e-journal]. 13. Disponible en: $<\mathrm{http}: / /$ edutec.rediris.es/ Revelec2/Revelec13/urbina.html> [Consultado: 18 de Mayo de 2012]. 